\title{
PREVALENGE OF DEPRESSIVE SYMPTOMS AMONG YOUNG ADULTS IN SZCZECIN
}

\author{
Marta Stępień-Słodkowska, , A, B, D Hanna Kostkiewicz, ${ }^{1, A, B, D}$ Katarzyna Kotarska, , C, D, E \\ Bożena Kawicka², B, D
}

\author{
${ }^{1}$ Faculty of Physical Culture and Health Promotion, University of Szczecin, Poland \\ ${ }^{2}$ The Clinic of Somatopsychology and Psychotherapy for Children and Adults, Szczecin, Poland \\ A Study Design; ${ }^{\mathrm{B}}$ Data Collection; ${ }^{\mathrm{C}}$ Statistical Analysis; ${ }^{\mathrm{D}}$ Manuscript Preparation; ${ }^{\mathrm{E}}$ Funds Collection \\ Address for correspondence: \\ Marta Stępień-Słodkowska \\ Faculty of Physical Culture and Health Promotion, University of Szczecin \\ Al. Piastów 40 b, bl. 6, 71-065 Szczecin, Poland \\ E-mail: marta.stepien-slodkowska@usz.edu.pl
}

\begin{abstract}
Ahstract Depressive disorders have become one of the greatest health problems of the modern society, with about 350 million people suffering from depression around the world (WHO). The aim of this study was to determine the prevalence of symptoms of depressed mood and symptoms indicating the possibility of depression or its progression among young people living in the city of Szczecin, Poland. Data from 150 students (107 women and $43 \mathrm{men}$ ) from one of the local universities constituted the material for this anonymous study which was based on the Beck Depression Inventory - 21 questions assessing the severity of depressive symptoms. Our results showed that $78 \%$ of women and $89 \%$ of men did not show symptoms of depression (Figure 1). The incidence of mild depressive episodes was revealed in $15 \%$ of women and $7 \%$ of men, moderate episodes in $3 \%$ of women and $2 \%$ of men, and severe depression in $4 \%$ of women and $2 \%$ of men.
\end{abstract}

Key Worlls depression, mood reduction, Beck Depression Inventory, students

\section{Introduction}

The term 'depression' is often used colloquially to describe any feeling of depressed mood and dejection (Pużyński, 2009). In psychiatry it relates to mood and emotion disorders which last longer than the transient feeling of dejection (Kużel, Krajewska-Kułak, Śmigielska-Kuzia, 2015). The disorder impairs the proper functioning and quality of life in every aspect of health, whether physical, social, mental or sexual. It leads to the disturbance of basic biological and cognitive functions, and consequently changes human behavior. The etiology of depression is not well understood, but it is evident that it is caused by many coexisting factors (Kużel et al., 2015; Han, Pae, 2015). These include genetic factors, serotonin metabolism disorders, drug and psychoactive substance abuse, as well as stressful situations or failures and the anxiety or stress reactions they entail. Increasingly, mood disorders and depression are being associated with other civilization diseases, such as cardiovascular diseases or obesity (Ufnal, 
Wolynczyk-Gmaj, 2011; Kerling et al., 2015). Therefore, the treatment of depression should be conducted in an interdisciplinary manner by psychiatrists and other medical and paramedical specialists, depending on the individual needs of each patient. The ICD-10 classification of somatic symptoms used in the diagnosis of depressive states includes waking in the morning several hours before the usual time, marked psychomotor retardation, agitation, loss of appetite, weight loss, and loss of libido (Święcicki, 2002).

Depressive disorders have become one of the greatest health problems in society, with depressive symptoms present in human populations all over the world (Grygorczuk, 2008; Hallstrom, McClure, 2007). According to the World Health Organisation (WHO), depression affects about 350 million people worldwide (Smith, 2014). In Poland, the percentage of people affected by depression is estimated at $2 \%$. According to a report by the World Health Organization, by 2020 depression may become the second largest health threat after cardiovascular diseases.

There are many social campaigns in Poland aimed at raising public awareness of the causes and symptoms of depression and the institutions which offer adequate help. The $23^{\text {rd }}$ of February is a National Depression Day. The Ithaca Foundation runs a website "Depression is an illness. You may cure it!" and the campaign "Live, don't die", which draws particular attention to the problem of suicide as the most serious consequence of untreated depression. The "Forum Against Depression" has also been operating in Poland since 2007. Its aim is to spread knowledge and make the public aware of the significance of depression as a health problem, that it is not just a temporary condition but a serious disease that should be treated (https://forumprzeciwdepresji.pl, access 17.09.2018).

\section{Objective of the study}

The aim of the study was to determine the prevalence of depressed mood and symptoms indicating the possibility of depression or its development among young people.

\section{Material and test methods}

Data from 150 students (107 women and 43 men) from one of the universities in Szczecin constituted the material for the study. The age of the respondents ranged from 18 to 27 years ( $M=21.61$ ). The data from the respondents were obtained by means of a questionnaire (Babbie, 2009). The anonymous study was a Beck Depression Inventory consisting of 21 questions assessing the severity of depressive symptoms in patients (Beck, Ward, Mendelson, Mock, Erbaugh, 1961). The sum of points indicates the severity of depression. Eleven (11) points or less denotes minimal depression, 12 to 26 points are mild depression, 27 to 49 points moderate depression, and 50 points or more indicate severe depressive episodes.

\section{Test results}

Table 1 shows the severity of depressive symptoms in the studied population.

Table 1. Characteristics of depressive symptoms of the subjects

\begin{tabular}{|c|c|c|}
\hline Question & Options for responses & $\begin{array}{l}\text { Number } \\
\text { of subjects }\end{array}$ \\
\hline 1 & 2 & 3 \\
\hline \multirow{4}{*}{1.} & I do not feel sad (0) & 103 \\
\hline & I feel sad (1) & 39 \\
\hline & I am sad all the time and I can't snap out of it (2) & 6 \\
\hline & I am so sad and unhappy that I can't stand it (3) & 2 \\
\hline
\end{tabular}




\begin{tabular}{|c|c|c|}
\hline 1 & 2 & 3 \\
\hline \multirow{4}{*}{2.} & I am not particularly discouraged about the future $(0)$ & 59 \\
\hline & I feel discouraged about the future (1) & 80 \\
\hline & I feel I have nothing to look forward to (2) & 9 \\
\hline & I feel the future is hopeless and that things cannot improve (3) & 2 \\
\hline \multirow{4}{*}{3.} & I do not feel like a failure $(0)$ & 115 \\
\hline & I feel I have failed more than the average person (1) & 27 \\
\hline & As I look back on my life, all I can see is a lot of failures (2) & 8 \\
\hline & I feel I am a complete failure as a person (3) & 0 \\
\hline \multirow{4}{*}{4.} & I get as much satisfaction out of things as I used to (0) & 121 \\
\hline & I don't enjoy things the way I used to (1) & 21 \\
\hline & I don't get real satisfaction out of anything anymore (2) & 8 \\
\hline & I am dissatisfied or bored with everything (3) & 0 \\
\hline \multirow{4}{*}{5.} & I don't feel particularly guilty $(0)$ & 98 \\
\hline & I feel guilty a good part of the time (1) & 46 \\
\hline & I feel quite guilty most of the time (2) & 2 \\
\hline & I feel guilty all of the time (3) & 4 \\
\hline \multirow{4}{*}{6.} & I don't feel I am being punished $(0)$ & 133 \\
\hline & I feel I may be punished (1) & 14 \\
\hline & I expect to be punished (2) & 2 \\
\hline & I feel I am being punished (3) & 1 \\
\hline \multirow{4}{*}{7.} & I don't feel disappointed in myself $(0)$ & 120 \\
\hline & I am disappointed in myself (1) & 25 \\
\hline & I am disgusted with myself (2) & 5 \\
\hline & I hate myself (3) & 0 \\
\hline \multirow{4}{*}{8.} & I don't feel I am any worse than anybody else $(0)$ & 122 \\
\hline & I am critical of myself for my weaknesses or mistakes (1) & 24 \\
\hline & I blame myself all the time for my faults (2) & 4 \\
\hline & I blame myself for everything bad that happens (3) & 0 \\
\hline \multirow{4}{*}{9.} & I don't have any thoughts of killing myself $(0)$ & 141 \\
\hline & I have thoughts of killing myself, but I would not carry them out (1) & 7 \\
\hline & I would like to kill myself (2) & 1 \\
\hline & I would kill myself if I had the chance (3) & 1 \\
\hline \multirow{4}{*}{10.} & I don't cry any more than usual $(0)$ & 125 \\
\hline & I cry more now than I used to (1) & 18 \\
\hline & I cry all the time now (2) & 3 \\
\hline & I used to be able to cry, but now I can't cry even though I want to (3) & 4 \\
\hline \multirow{4}{*}{11.} & I am no more irritated by things than I ever was $(0)$ & 93 \\
\hline & I am slightly more irritated now than usual (1) & 43 \\
\hline & I am quite annoyed or irritated a good deal of the time (2) & 11 \\
\hline & I feel irritated all the time (3) & 3 \\
\hline \multirow{4}{*}{12.} & I have not lost interest in other people (0) & 100 \\
\hline & I am less interested in other people than I used to be (1) & 35 \\
\hline & I have lost most of my interest in other people (2) & 13 \\
\hline & I have lost all of my interest in other people (3) & 0 \\
\hline \multirow{4}{*}{13.} & I make decisions about as well as I ever could $(0)$ & 89 \\
\hline & I put off making decisions more than I used to (1) & 45 \\
\hline & I have greater difficulty in making decisions more than I used to (2) & 12 \\
\hline & I can't make decisions at all anymore (3) & 4 \\
\hline \multirow{4}{*}{14.} & I don't think that I look any worse than I used to $(0)$ & 128 \\
\hline & I am worried that I am looking old or unattractive (1) & 8 \\
\hline & I feel that there are permanent changes in my appearance that make me look unattractive (2) & 12 \\
\hline & I believe that I look ugly (3) & 2 \\
\hline
\end{tabular}




\begin{tabular}{|c|c|c|}
\hline 1 & 2 & 3 \\
\hline \multirow{4}{*}{15.} & I can work about as well as before $(0)$ & 124 \\
\hline & It takes an extra effort to get started at doing something (1) & 19 \\
\hline & I have to push myself very hard to do anything (2) & 6 \\
\hline & I can't do any work at all (3) & 1 \\
\hline \multirow{4}{*}{16.} & I can sleep as well as usual (0) & 103 \\
\hline & I don't sleep as well as I used to (1) & 39 \\
\hline & I wake up 1-2 hours earlier than usual and find it hard to get back to sleep (2) & 7 \\
\hline & I wake up several hours earlier than I used to and cannot get back to sleep (3) & 1 \\
\hline \multirow{4}{*}{17.} & I don't get more tired than usual $(0)$ & 103 \\
\hline & I get tired more easily than I used to (1) & 42 \\
\hline & I get tired from doing almost anything (2) & 2 \\
\hline & I am too tired to do anything (3) & 3 \\
\hline \multirow{4}{*}{18.} & My appetite is no worse than usual ( 0 ) & 127 \\
\hline & My appetite is not as good as it used to be (1) & 16 \\
\hline & My appetite is much worse now (2) & 3 \\
\hline & I have no appetite at all anymore (3) & 4 \\
\hline \multirow{4}{*}{19.} & I haven't lost much weight, if any, lately (0) & 115 \\
\hline & I have lost more than five pounds (1) & 22 \\
\hline & I have lost more than ten pounds (2) & 7 \\
\hline & I have lost more than fifteen pounds (3) & 6 \\
\hline \multirow{4}{*}{20.} & I am no more worried about my health than usual $(0)$ & 122 \\
\hline & I am worried about physical problems like aches, pains, upset stomach, or constipation (1) & 14 \\
\hline & I am very worried about physical problems and it's hard to think of much else (2) & 9 \\
\hline & I am so worried about my physical problems that I cannot think of anything else (3) & 5 \\
\hline \multirow{4}{*}{21.} & I have not noticed any recent change in my interest in sex (0) & 135 \\
\hline & I am less interested in sex than I used to be (1) & 10 \\
\hline & I have almost no interest in sex (2) & 0 \\
\hline & I have lost interest in sex completely (3) & 5 \\
\hline
\end{tabular}

Our results showed that $78 \%$ of women and $89 \%$ of men did not show depressive symptoms (Figure 1). The incidence of mild depressive episodes was revealed in $15 \%$ of women and $7 \%$ of men, moderate episodes in $3 \%$ of women and $2 \%$ of men, and severe depression in $4 \%$ of women and $2 \%$ of men.

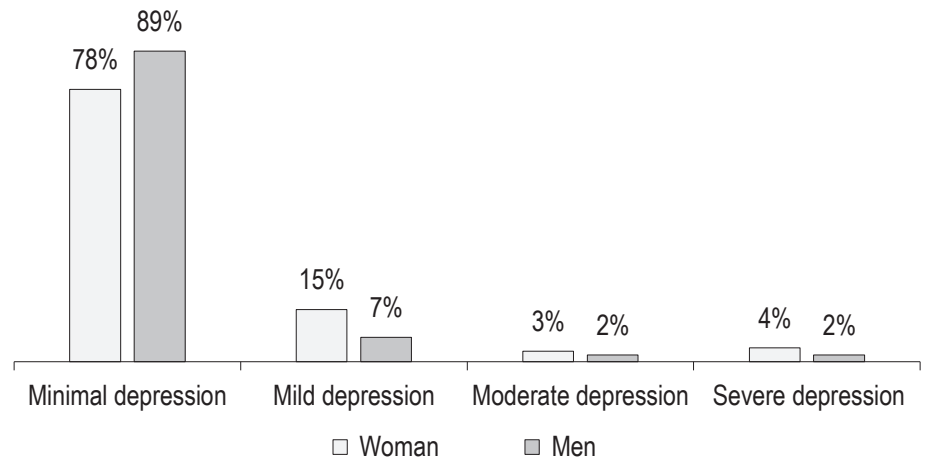

Figure 1. Intensification of depressive symptoms among the studied students depending on gender 


\section{Discussion}

The start of university studies is an important stage in the life of every young person, and often means changing the social and family environment, different place of residence and, above all, beginning an independent life. Such a large amount of stressful stimuli and pressure combined with a high level of independence may often cause an adjustment disorder which significantly hinders adaptation to the new conditions and normal functioning of young people (Radochoński, 2001).

A drop in mood is usually associated with sadness, weeping, and dejection. However, young people express their depressed mood through anger and aggression. Such behavior discourages contact and thus makes it more difficult to provide assistance. There are also instances of aggressive behaviors towards other people, propensity to conflicts, impulsive expression of emotions or other violent behaviors. It is usually a consequence of constant tension, irritation and irritability. Those who are around people suffering from depression are often surprised by the fact that the person reacts violently or excessively to calm statements or remarks. Therefore, it should be remembered that in young people a lowered mood is associated with elevated irritability. A young person with depression will often enter into numerous conflicts, quarrels or discussions with teachers and parents. Unpleasant situations are constantly re-lived and repeated in the mind, which even more affects their mood. An additional problem is often that their family and friends do not notice the symptoms or ignore them, which means that young people do not receive proper help.

One of the groups at high risk of developing depression are university students (Jaworska, Morawska, Morga, Szczepańska-Gieracha, 2014; Białkowska, Mroczkowska, Zomkowska, Rakowska, 2014). Students because of the symptoms of the disease do not fully develop their development potential (Mojs et al., 2015). The research conducted by K. Marek et al. (2005) on a group of 206 students of the Medical University of Gdańsk showed that this population was characterized by a relatively high level of anxiety, and their intensity was much higher in the first year of studies than in the following years. Anxiety symptoms were often accompanied by a sense of loneliness and excessive burden. The research also found that young people most often applied strategies requiring social contact to solve the problem, but a large percentage of respondents negated the need for psychiatric treatment of mood disorders or depression.

Any change in life can cause stress. It usually takes several months to adapt to a change. Students are especially at risk of depression in two periods: at the beginning and at the end of their studies. The two main symptoms include reduced mood and a loss of interest in any life activity. Some depressive symptoms are associated just with the reduced sense of well-being, while not losing interest in their studies. Students are still learning, and they blame the stresses of their daily life for their depressed mood. They do not abandon their studies, but also do not decide to receive treatment, which may lead to a further reduction in their mood or full-blown depression, which turns to a chronic state. On the other hand, some students who suffer from depression are inclined to abandon their studies, which aggravates the symptoms even further.

Numerous studies indicate that a high proportion of university students have adjustment problems. According to a study by the National College of Health Assessment, one third of students at one point "felt so depressed that they were unable to function". In addition, mental health problems are more common among university students than among the general population. As a result of the research conducted in Olsztyn, one in eight students was found to be at risk of mood disorders (Marek et al., 2005). It showed some gender-related differences in terms of sleep 
problems, frequent awakening or excessive sleepiness, fatigue or lack of energy, eating disorders. In addition, women were the most vulnerable group in term of risk of depression.

Although depression studies in a group of university students are important from the point of view of public health, their results cannot be generalized for the whole population (Vredenburg, Flett, Krames, 1993). T. Pietras et al. (2012) believe that education is important for shaping young people's attitudes and views. Educational institutions are places where immature young people are intensively socialized, and where they can shape their views and characteristic attitudes on their own. This period of schooling at each stage can be both pleasant and traumatic, often resulting in psychosocial disorders.

Our research did not confirm mood disorders and symptoms of depression in the majority of the surveyed university student in Szczecin. However, we did find symptoms of mild depression in $15 \%$ of women and $7 \%$ of men. More worryingly, moderate depression was observed in $3 \%$ of women and $2 \%$ of men, and severe depression symptoms were found in $4 \%$ of women and $2 \%$ of men. Moreover, it was noted that women were more at risk of a mood reduction and depressive episodes. A review of available research results shows that gender is an important predictor of mood disorders. Women experience higher levels of depression than men as a result of, inter alia, a gender-specific perception of stressful situations (Rosal et al., 1997). Accordingly, women of all ages are more likely to meet the diagnostic criteria of anxiety disorders and eating disorders (Lewinsohn, Hops, Roberts, Seeley, Andrews, 1993). Higher exposure of women to stress was also observed in a study by M. Dahlin, N. Joneborg, B. Runeson (2005) where the incidence of depressive symptoms among students was about $13 \%$, and also significantly higher in women than in men. The highest number of mood disorders was observed among students in earlier years, where most of them experienced the highest level of pressure associated with studying.

To sum up, it should be noted that studies on the prevalence of depression in groups of students are important from the point of view of public health, although the results do not allow making generalizations regarding the entire population. This is due to the relative scarcity of scientific reports on mood disorders and depression among young people. So far, research papers have been characterized by a high randomness in terms of the selection of methods and a diverse number of groups, thus making it impossible to make generalized conclusions regarding the research subject matter. Therefore, it is advisable to conduct extended psychological research, and diagnose the causes of depressive episodes in young adults. We should not forget, either, how important health education is in preventing depression and other civilization diseases. Young people leaving their primary families should be equipped with the resources that enable them to function properly in society, cope with difficult situations and maintain their ability to cope with a changing environmental and living conditions. The emphasis on the importance of the family in this respect should be supported by appropriate educational measures in every educational institution and at every level.

\section{References}

Babbie, E. (2009). Podstawy badań społecznych. Warszawa: Wydawnictwo Naukowe PWN.

Beck, A.T., Ward, C.H., Mendelson, M., Mock, J., Erbaugh, J. (1961). An inventory for measuring depression. Archives of General Psychiatry, 4, 53-63.

Białkowska, J., Mroczkowska, D., Zomkowska, E., Rakowska, A. (2014). Ocena zdrowia psychicznego studentów na podstawie Skróconego Kwestionariusza Zdrowia Pacjenta. Hygeia Public Health, 49 (2), 365-369.

Dahlin, M., Joneborg, N., Runeson, B. (2005). Stress and depression among medical students: a cross-sectional study. Med Educ, 39 , 594-604. 
Gregorczuk, A. (2008). Związek zaburzeń depresyjnych nawracających z płcią psychologicznąi sposobami radzenia sobie w sytuacjach stresowych. Psychiatria, 25 (1), 13-22.

Hallstrom, C., McClure, N. (2007). Depresja. Odpowiedzi na pytania. Wrocław: Elsevier Urban \& Partner.

Han, C., Pae, C. (2015). Pain and depression: a neurobiological perspective of their relationship. Korean Neuropsychiatric Association. DOI: 10.4306/pi.2015.12.1.1.

https://forumprzeciwdepresji.pl (17.09.2018).

Jaworska, L., Morawska, N., Morga, P., Szczepańska-Gieracha, J. (2014). Analiza częstości występowania objawów depresyjnych wśród studentów Wydziału Fizjoterapii Akademii Wychowania Fizycznego we Wrocławiu w kontekście planów zawodowych. Fizjoterapia, 22 (3), 10-22. DOI: 10.1515/physio-2014-0007.

Kerling, A., Tegtbur, U., Gützlaff, E., Kück, M., Borchert, L., Ates, Z., von Bohlen, A., Frieling, H., Hüper, K., Hartung, D., Schweiger, U., Kahl, K.G. (2015). Effects of adjunctive exercise on physiological and psychological parameters in depression: a randomized pilot trial. Journal of affective disorders, 177, 1-6.

Kużel, A., Krajewska-Kułak, E., Śmigielska-Kuzia, J. (2015). Percepcja depresji w wybranych grupach społecznych. Medycyna Ogólna i Nauki o Zdrowiu, 21 (3), 295-302.

Lewinsohn, P.M., Hops, H., Roberts, R.E., Seeley, J.R., Andrews, J.A. (1993). Adolescent psychopathology: I. Prevalence and incidence of depression and other DSM-III - Disorders in high school students. J Abnormal Psychol, 102 (1), 133-144.

Marek, K., Białoń, P., Wichowicz, H., Melloch, H., Nitka-Siemińska, A. (2005). Przesiewowa ocena rozpowszechnienia objawów depresyjnych i lękowych wśród studentów Akademii Medycznej w Gdańsku. Psychiatria, 2 (4), 217-224.

Mojs, E., Bartkowska, W., Kaczmarek, Ł.D., Ziarko, M., Bujacz, A., Warchoł-Biedermann, K. (2015). Właściwości psychometryczne polskiej wersji skróconej Skali Depresji Kutchera dla Młodzieży (Kutcher Adolescent Depression Scale) - pomiar depresji w grupie studentów. Psychiatria Polska, 49 (1),135-144.

Pietras, T., Witusik, A., Panek, M., Zielińska-Wyderkiewicz, E., Kuna, P., Górski, P. (2012).Nasienie depresyjności u studentów kierunku pedagogika. Pol Merk Lek, 32 (189), 163-166.

Pużyński, S. (2009). Depresje i zaburzenia efektywne. Warszawa: Wydawnictwo Lekarskie PZWL.

Radochoński, M. (2001). Podstawy psychopatologii dla pedagogów. Rzeszów: Wydawnictwo Uniwersytetu Rzeszowskiego.

Rosal, M.C, Ockene, I.S, Ockene, J.K, Barrett, S.V, Ma, Y., Hebert, J.R. (1997). A Longitudinal study of students' depression at one medical school. Acad Med, 72 (6), 542-546.

Smith, K. (2014). Menthal health: a world of depression. Nature, 13 (515), 181-190. DOI: 10.1038/515180a.

Święcicki, Ł. (2002). Depresja - definicja, klasyfikacja, przyczyny. Warszawa: Via Medica.

Ufnal, M., Wolynczyk-Gmaj, D. (2011). Mózg i cytokiny - wspólne podłoże depresji, otyłości i chorób układu krążenia? Postępy Higieny i Medycyny Doświadczalnej, 65, 228-235.

Vredenburg, K., Flett, G.L., Krames, L. (1993). Analogue versus clinical depression: a critical reappraisal. Psychol Bull, 113 (2), $327-344$.

Cite this article aS:. Stępień-Słodkowska, M., Kostkiewicz, H., Kotarska, K., Kawicka, B. (2019). Prevalence of Depressive Symptoms among Young Adults in Szczecin. Central European Journal of Sport Sciences and Medicine, 1 (25), 15-21. DOI: 10.18276/ cej.2019.1-02. 